\title{
KONTRIBUSI KEPEMIMPINAN KEPALA SEKOLAH, ETOS KERJA, KEPUASAN KERJA, DAN BUDAYA ORGANISASI SEKOLAH TERHADAP KINERJA GURU DI SMKN 2 SINGARAJA
}

\author{
Ni Made Muliartini, I Nyoman Natajaya, I Gusti Ketut Arya Sunu \\ Program Studi Administrasi Pendidikan, Program Pascasarjana \\ Universitas Pendidikan Ganesha \\ Singaraja, Indonesia
}

e-mail: \{made.muliartini, nyoman.natajaya, arya.sunu\}@pasca.undiksha.ac.id.

\begin{abstract}
Abstrak
Penelitian ini bertujuan untuk mengetahui kontribusi kepemimpinan kepala sekolah, etos kerja, kepuasan kerja, dan budaya organisasi sekolah terhadap kinerja guru di SMKN 2 Singaraja. Penelitian ini adalah penelitian "ex-post facto" dengan besar sampel 86 orang. Data dikumpulkan dengan kuesioner dan dokumen. Analisis data dilakukan dengan teknik regresi sederhana, regresi ganda, dan korelasi parsial. Hasil penelitian menunjukkan bahwa: (1) terdapat kontribusi yang signifikan antara kepemimpinan terhadap kinerja guru dengan koefisien korelasi sederhana sebesar 0,517 , korelasi parsial 0,256 dan sumbangan efektifnya sebesar $10,74 \%$, (2) terdapat kontribusi yang signifikan antara etos kerja terhadap kinerja guru dengan koefisien korelasi sederhana sebesar 0,564, korelasi parsial 0,283 dan sumbangan efektifnya sebesar $13,61 \%$, (3) terdapat kontribusi yang signifikan antara kepuasan kerja terhadap kinerja guru dengan korelasi sederhana sebesar 0,613, korelasi parsial 0,298 dan sumbangan efektifnya sebesar $16,75 \%$, (4) terdapat kontribusi yang signifikan antara budaya organisasi terhadap kinerja guru dengan koefisien korelasi sederhana sebesar 0,564, korelasi parsial 0,288 dan sumbangan efektifnya sebesar $13,73 \%$, (5) secara bersama-sama, terdapat kontribusi yang signifikan antara kepemimpinan, etos kerja, kepuasan kerja, dan budaya organisasi terhadap kinerja guru dengan koefisien korelasi ganda sebesar 0,794 dan kontribusinya sebesar 54,8\% terhadap kinerja guru. Dengan demikian keempat variable tersebut dapat dijadikan prediktor tingkat kecenderungan peningkatan kinerja guru di SMK 2 Singaraja.
\end{abstract}

Kata kunci: kepemimpinan, etos kerja, kepuasan kerja, budaya organisasi, kinerja guru

\begin{abstract}
This study aims to determine the contribution of principal leadership, work ethic, job satisfaction, and school organizational culture on teacher performance in SMKN 2 Singaraja. This research is an "expost facto" research with a large sample of 86 people. Data were collected with questionnaires and documents. Data analysis was performed by simple regression, multiple regression, and partial correlation. The results showed that: 1) there was a significant contribution between leadership on teacher performance with correlation coefficient of 0,517 , partial correlation of 0,256 and effective contribution of $10,74 \%$. 2) there is a significant contribution between the work ethic on teacher performance with a correlation coefficient of 0,564 , partial correlation of 0,283 and effective contribution of $13,61 \%$. 3) there is a significant contribution between job satisfaction on teacher performance with correlation coefficient of 0,613 , partial correlation of 0,298 and effective contribution equal to $16,75 \%$. 4) there is a significant contribution between organizational culture on teacher performance with correlation coefficient of 0,564 , partial correlation of 0,288 and effective contribution equal to $13,73 \%$. 5) jointly, there is a significant contribution between leadership, work ethic, job satisfaction, and organizational culture on teacher performance with a double correlation coefficient of 0,794 and its contribution of $54,8 \%$ to teacher performance. Thus the four variables can be used as a predictor of the level of teacher performance improvement tendency in SMK 2 Singaraja.
\end{abstract}

Keywords: leadership, work ethic, job satisfaction, organizational culture, teacher performance 


\section{PENDAHULUAN}

Guru adalah figur yang menempati posisi memegang peranan penting dalam pendidikan. Ketika semua orang mempersoalkan masalah mutu pendidikan figur guru mesti terlibat dalam agenda pembicaraan terutama yang menyangkut persoalan pendidikan formal di sekolah. Pendidik atau guru merupakan tenaga profesional yang bertugas merencanakan dan melaksanakan proses pembelajaran, menilai hasil pembelajaran, melakukan pembimbingan dan pelatihan, serta melakukan penelitian dan pengabdian kepada masyarakat. Hal tersebut tidak dapat disangkal karena lembaga pendidikan formal adalah dunia kehidupan guru, sebagian besar waktu guru ada di sekolah, sisanya ada di rumah dan masyarakat (Djamarah, 2000:32).

Guru dituntut memiliki kinerja yang mampu memberikan dan merealisasikan harapan dan keinginan semua pihak terutama masyarakat umum yang telah mempercayai sekolah dan guru dalam membina anak didik. Dalam meraih mutu pendidikan yang baik sangat dipengaruhi oleh kinerja guru dalam melaksanakan tugasnya sehingga kinerja guru menjadi tuntutan penting untuk mencapai keberhasilan pendidikan.Secara umum mutu pendidikan yang baik menjadi tolok ukur bagi keberhasilan kinerja yang ditunjukkan guru.

Permasalahan umum yang saat ini masih menimpa dunia pendidikan kita juga terjadi dalam penyelenggaraan pendidikan yang dialami SMKN 2 Singaraja, yaitu kemampuan guru dalam mengajar masih sangat rendah. Maka untuk mengatasi dan mengantisipasi rendahnya mutu pendidikan salah satu cara yang dapat dilakukan adalah dengan meningkatkan kualitas pelayanan pendidikan. Untuk meningkatkan pelayanan pendidikan pada tingkat instruksional harus dimulai dari peningkatan kualitas layanan yang secara operasional dilaksanakan oleh guru.

Pada dasarnya, kinerja guru dipengaruhi oleh faktor dari dalam (internal) guru itu sendiri yaitu bagaimana guru menyikapi tugas dan tanggung jawab yang diemban. Sedangkan faktor dari luar (eksternal) yang berpengaruh pada kinerja guru yaitu kepemimpinan kepala sekolah, adanya etos kerja, kepuasan kerja dan budaya organisasi. Kepala sekolah sebagai pengelola pendidikan dalam satuan pendidikan memegang peranan penting untuk memberikan bantuan pada perkembangan kemampuan guru dan personil sekolah lainnya dalam upaya mencapai tujuan pendidikan. Bantuan itu berupa dorongan, bimbingan, dan kesempatan bagi pertumbuhan, keahlian, dan kecakapan guru seperti bimbingan dalam usaha dan pelaksanaan pemabharuan dalam pendidikan dan pengajaran, pemilihan alat-alat pelajaran dan metoda mengajar yang lebih baik, serta cara-cara penilaian yang sistematis terhadap fase dari seluruh proses pengajaran.

Keberhasilan pendidikan khususnya di sekolah juga ditentukan oleh keberhasilan kepala sekolah dalam mengelola tenaga kependidikan yang tersedia di sekolah. Kepala sekolah merupakan salah satu komponen pendidikan yang berpengaruh dalam peningkatan kinerja guru. Kepala sekolah bertanggung jawab atas penyelenggaraan kegiatan pendidikan, administrasi sekolah, pembinaan tenaga kependidikan lainnya, dan pendayagunaan serta pemeliharaan sarana dan prasarana (Mulyasa, 2004:25). Hal tersebut menjadi lebih penting sejalan dengan semakin kompleksnya tuntutan tugas kepala sekolah yang menghendaki dukungan kinerja yang semakin efektif dan efisien.

Kepemimpinan kepala sekolah yang baik harus dapat mengupayakan peningkatan kinerja guru melalui program pembinaan kemampuan tenaga kependidikan. Oleh karena itu, kepala sekolah harus mempunyai integritas kepribadian sebagai pemimpin atau mempunyai sifat serta kemampuan untuk memimpin sebuah lembaga pendidikan. Hal ini sejalan dengan peraturan Menteri Pendidikan Nasional Nomor 13 tahun 2007 tentang Standar Kepala Sekolah yang menyatakan bahwa: "Kepala sekolah harus memiliki kompetensi manajerial yang diharapkan mampu memimpin sekolahnya dalam rangka mendayagunakan sumber daya sekolah secara optimal" (Depdiknas, 2008:8).

Variabel yang diduga juga berhubungan dengan kinerja guru adalah etos kerja. Etos kerja pada initinya adalah suatu sikap guru terhadap kerja yang dicirikan oleh adanya bekerja tulus penuh syukur, bekerja benar penuh tanggung jawab, kerja tuntas penuh 
integritas, bekerja keras penuh semangat, bekerja serius penuh kecintaan, bekerja kreatif penuh sukacita, bekerja tekun penuh keunggulan, bekerja sempurna penuh kerendahan hati. Apabila seseorang memiliki ciri-ciri seperti ini akan berdampak pada kinerjanya.

Etos kerja merupakan sikap terhadap kerja, sehingga dalam diri seseorang atau sekelompok orang dan organisasi menyikapi paradigma kerja menjadi berbeda, ada yang positif, ada yang negatif, ada yang tinggi ada yang rendah, sehingga timbullah contoh etos kerja tinggi, etos kerja rendah, dan seterusnya. Panji Anoraga dan Suryanti (1995:14) mengidentifikasi dua kutub seseorang atau sekelompok masyarakat memiliki etos kerja yakni memiliki etos kerja tinggi dan etos kerja rendah. Individu atau kelompok masyarakat memiliki etos kerja tinggi jika menunjukan tanda-tanda adalah: (1) mempunyai penilaian yang sangat positif terhadap hasil kerja manusia, (2) menempatkan pandangan tentang kerja sebagai suatu hal yang sangat luhur bagi eksistensi manusia, (3) kerja dirasakan sebagai aktivitas yang bermakna bagi kehidupan manusia, (4) kerja dihayati sebagai suatu proses yang membutuhkan ketekunan dan sekaligus sarana yang penting dalam mewujudkan cita-cita, dan (5) kerja dilakukan sebagai ibadah. Sedangkan bagi individu atau masyarakat yang memiliki etos kerja yang rendah, akan menunjukkan ciri-ciri yang sebaliknya, yaitu: (1) kerja dirasakan sebagai suatu hal yang membebani diri, (2) kurang dan bahkan tidak menghargai hasil kerja manusia, (3) kerja dipandang sebagai penghambat dalam memperoleh kesenangan, (4) kerja dilakukan sebagai bentuk keterpaksaan, dan (5) kerja dihayati hanya sebagai bentuk rutinitas hidup. Bisa dibayangkan, suatu organisasi yang diisi oleh individu atau sekumpulan individu dengan etos kerja rendah, maka produktivitas kerja akan menurun, kondisi kerja tak kondusif, tingkat kehadiran yang rendah, yang banyak terjadi adalah keluhan, dan tuntutan, bukan memberikan andil untuk peningkatan kinerja.

Kepuasan kerja dapat dipahami melalui tiga aspek. Pertama, kepuasan kerja merupakan bentuk respon pekerja terhadap kondisi lingkungan pekerjaan. Kedua, kepuasan kerja sering ditentukan oleh hasil pekerjaan atau kinerja. Ketiga, kepuasan kerja terkait dengan sikap lainnya dan dimiliki oleh setiap pekerja (Luthans 1995:241). Smith et al. $(1996: 87)$ secara lebih rinci mengemukakan berbagai dimensi dalam kepuasan kerja yang kemudian dikembangkan menjadi instrumen pengukur variabel kepuasan terhadap (1) menarik atau tidaknya jenis pekerjaan yang dilakukan oleh pekerja, (2) jumlah kompensasi yang diterima pekerja, (3) kesempatan untuk promosi jabatan, (4) kemampuan atasan dalam memberikan bantuan teknis dan dukungan perilaku, dan dukungan rekan sekerja (Maryani dan Supomo 2001:66).

Dampak dari meningkatnya kepuasan kerja: Produktivitas kerja meningkat, menurunnya kemangkiran dan permintaan berhenti, dan kesehatan pegawai yang meningkat karena perasaan nyaman terhadap pekerjaan. (Sunyoto, 2000:167).

Budaya organisasi merupakan unsur dinamis yang ada pada tempat dimana ia bekaerja. Budaya organisasi bagi guru adalah budaya sekolah yaitu segala sesuatu yang ada di dalam organisasi sekolah, baik fisik maupun sosial. Budaya organisasi yang baik akan memberikan dorongan (motivasi) pada setiap individu yang ada, dan dalam struktur organisasi tersebut harus dapat bekerja dengan nyaman dan maksimal. Sebaliknya budaya organisasi yang kurang mendukung akan mempengarhi motivasi kerja menjadi semakin menurun.

Setiap individu dalam sebuah lembaga pendidikan berbeda antara satu sama lain. Seperti layaknya manusia, sebuah sekolah memilki getaran dan jiwa senndiri yang penting berbeda satu sama lainnya. Getaran tersebut berasal dari lingkungan sekolah yang gilirannya menciptakan budaya sebuah lembaga pendidikan.

Robbin (1996:221) mengatakan bahwa "budaya organisasi adalah suatu persepsi bersama yang dianut oleh anggota-anggota organisasi yaitu suatu makna bersama". Sistem makna tersebut merupakan karakteristik utama yang dihargai oleh organisasi. Sekolah sebagai sebuah organisasi pendidikan yang memberikan pelayanan kepada masyarakat dibidang pendidikan, harus memiliki norma, nilai-nilai, dan kepercayaan terhadap pelayanan masyarakat. 
Budaya organisasi merupakan perpaduan nilai-nilai, kayakinan, asumsi-asumsi, pemahaman, dan harapan yang diyakini oleh anggota organisasi atau kelompok serta dijadikan pedoman berprilaku dan memecahkan masalah yang mereka hadapi. Adanya hubungan baik antar personil yang ada dalam organisasi akan berpengarauh terhadap munculnya tingkah laku sosial. Hoy dan Miskel (dalam Putra, 2008:5) mengemukakan ada tiga unsur yang mempengaruhi tingkah laku sosial, yaitu: 1) lembaga (tujuan institusi), 2) kelompok (harapan-harapan kelompok), dan 3) unsur individu (kebutuhan-kebutuhan individu).

Berdasarkan uraian di atas, terlihat bahwa kepemimpinan kepala sekolah, etos kerja, kepuasan kerja dan budaya organisasi terhadap kinerja guru di SMKN 2 Singaraja merupakan faktor yang cukup menentukan tingkat kinerja guru. Sehingga dapat diduga rendahnya kinerja guru di SMKN 2 Singaraja disebabkan oleh kepemimpinan kepala sekolah yang kurang efektif, minimnya etos kerja, kurangnya kepuasan kerja serta budaya organisasi di sekolah yang kurang kondusif. Berdasarkan hal tersebut, peneliti merasa tertarik untuk mengadakan penelitian dengan judul "Kontribusi Kepemimpinan Kepala Sekolah, Etos Kerja, Kepuasan Kerja, dan Budaya Organisasi Sekolah terhadap Kinerja Guru di SMKN 2 Singaraja".

\section{METODE PENELITIAN}

Penelitian ini termasuk penelitian ex post facto yang berbentuk korelasional karena variabel-variabel bebasnya tidak dikontrol secara langsung, tidak ada sebelumnya dan tidak dapat dimanipulasi. Kerliner memberikan batasan penelitian ex post facto adalah penyelidikan empiris sistematis, di mana ilmuwan tidak mengendalikan variabel bebas secara langsung karena perwujudan variabel tersebut telah terjadi ,atau karena variabel tersebut pada dasarnya memang tidak dimanifulasi. Disebut penelitian korelasional, karena penelitian ini bertujuan untuk mengetahui korelasi antara variabel-variabel bebas baik sendiri-sendiri maupun bersama-sama dengan variabel terikatnya.

Penentuan populasi sangat penting dilakukan sebelum penelitian dilaksanakan untuk memudahkan dalam penarikan kesimpulan. Menurut Agung $(2014 ; 69)$ menyatakan populasi adalah keseluruhan objek dalam suatu penelitian. Sugiyono (2010:61) mengatakan bahwa populasi adalah wilayah generalisasi yang terdiri atas: objek/subjek yang mempunyai kualitas dan karakteristik tertentu yang ditetapkan oleh peneliti untuk dipelajari dan kemudian ditarik kesimpulan. Yang dimaksud populasi dalam penelitian ini adalah keseluruhan aspek jumlah atau jumlah keseluruhan dari unit analisa yang ciri - cirinya akan diduga. Dalam penelitian ini, populasi dari penelitian adalah guru di SMKN 2 Singaraja. Adapun sebaran populasi dari penelitian ini adalah 86 orang.

Tahap penentuan sampel, menurut Agung $(2016 ; 8)$ menyatakan bahwa sampel merupakan bagian dari populasi yang secara langsung dikenai penelitian. Menurut Arikunto (2006:134) jika populasi kurang dari 100 maka seluruh anggota populasi lebih baik menjadi sampel. Maka dari itu sampel yang dipakai dalam penelitian ini yaitu sampel jenuh. Sampel jenuh adalah sampel yang diambil dari keseluruhan populasi sehingga seluruh populasi guru "SMKN 2 Singaraja" menjadi sampel.

Dalam penelitian ini terdapat 2 (dua) jenis variabel, yaitu variabel independent dan dependent. Berdasarkan landasan teori dan perumusan hipotesis yang ada maka yang menjadi variabel bebas dalam penelitian ini adalah kepemimpinan kepala sekolah, etos kerja, kepuasan kerja, dan budaya organisasi. Sedangkan variabel terikatnya adalah kinerja guru.

Alat pengumpul data harus memenuhi persyaratan yaitu syarat validitas dan reliabilitas dalam mengungkap apa yang hendak diukur. Ada dua persyaratan yang hendak digunakan dalam pengumpulan data penelitian yaitu validitas dan reliabilitas (Hamzah, 2007:63). Validitas instrumen dalam penelitian ini meliputi dua segi yaitu validitas isi dan validitas butir. Validitas isi dibantu oleh dua orang ahli/ expert, kemudian dianalisis dengan teknik Gregory. 
Sebelum instrumen digunakan, maka perlu diuji dahulu validitas dari masing-masing pertanyaan yang ada sebagai alat pengambilan data. Dengan demikian terlebih dahulu diadakan uji coba terhadap kuisioner kemudian hasil uji coba ini dianalisis. Untuk menguji validitas butir rumus yang digunakan adalah rumus kontribusi product moment dari Pearson (Arikunto, 1995).

Pengujian terhadap reabilitas instrumen dilakukan melalui pendekatan ketetapan internal. Uji reliabilitas adalah ketepatan dan keajegan alat pengukur tersebut dalam menilai apa yang diinginkan, artinya kapanpun alat tersebut digunakan akan diperoleh hasil yang sama (Puger, 2004). Pengujian reliabilitas dengan rumus Alpha dari Crombach (Arikunto, 1997:164).

Kegiatan analisis data terdiri atas kegiatan pengolahan data dan analisis statistik. Kegiatan analisis data meliputi: 1) menyunting data secara manual. Penyuntingan dilakukan karena kemungkinan ada data yang tidak jelas, atau kesalahan dalam pengisian instrument, sehingga tidak memenuhi syarat untuk dianalisis, 2) mentabulasi data, dan 3) mengolah data dalam bentuk sesuai kebutuhan.

Untuk menguji hipotesis yang telah dirumuskan, terlebih dahulu dilakukan analisis data yang telah dikumpulkan. Dalam melakukan analisis data untuk penelitian ini dilakukan dengan tiga tahapan yakni: 1) tahap deskripsi data, 2) tahap pengujian persyaratan analisis, 3) tahap pengujian hipotesis.

Data yang telah diperoleh dari penelitian dideskripsikan menurut masing-masing variable. Oleh tujuannya seperti itu, maka akan dicari harga rerata (M), standar deviasi (SD), modus (Mo), dan median (Me) setiap variabel yang diteliti.

Setelah data dideskripsikan, maka analisis dilanjutkan dengan menggunakan teknik regresi sederhana, regresi ganda, dan korelasi varsial. Persyaratan yang berkaitan dengan teknik analisis data tersebut harus dibuktikan secara statistik.

Setelah seluruh uji prasyarat terpenuhi, maka dilanjutkan dengan uji hipotesis. Untuk menguji hipotesis pertama, kedua, ketiga dan keempat dalam penelitian ini digunakan teknik analisis korelasi sederhana (korelasi product moment pearson). Sedangkan untuk menguji hipotesis ke empat, digunakan teknik analisis korelasi ganda, regresi ganda, dan korelasi parsial. Untuk menganalisis uji hipotesis dalam penelitian ini digunakan program SPSS17.00 for windows.

\section{HASIL PENELITIAN DAN PEMBAHASAN}

\section{Kontribusi Kepemimpinan Kepala Sekolah terhadap Kinerja Guru di SMKN 2 Singaraja}

Berdasarkan analisis data yang telah dilakukan, Secara normatif ditemukan bahwa kepemimpinan berada pada kategori sangat baik. Selain itu, hasil analisis juga menunjukkan bahwa terdapat korelasi yang signifikan antara kepemimpinan dengan kinerja guru di SMK Negeri 2 Singaraja melalui persamaan garis regresi $\hat{y}=79,285+0,758$.X1dengan Freg $=$ $30,563(p<0,05)$. Sedangkan korelasi yang signifikan terjadi antara kepemimpinan dengan kinerja guru sebesar 0,517 dengan $\mathrm{p}<0,05$ dan variabel kepemimpinan dapat menjelaskan kinerja guru di SMK Negeri 2 Singaraja sebesar 26,7\%. Temuan ini mengindikasikan bahwa kepemimpinan mempunyai peranan penting dalam meningkatkan kinerja guru di SMK Negeri 2 Singaraja. Sumbangan efektif (SE) variabel kepemimpinan terhadap kinerja guru di SMK Negeri 2 Singaraja adalah sebesar 10,74\%.

Temuan dalam penelitian ini sejalan dengan temuan penelitian yang dilakukan oleh Asricita (2015) dengan judul Kontribusi Perilaku Kepemimpinan Kepala Sekolah, Iklim Kerja, dan Etos Kerja Terhadap Kinerja Guru Bimbingan Konseling Pada SMA Se Kabupaten Tabanan. Hasil analisis ditemukan: (1) terdapat kontribusi yang positif dan signifikan antara perilaku kepemimpinan kepala sekolah terhadap kinerja guru bimbingan konseling sebesar $18,4 \%$, sumbangan relatif sebesar $70 \%$, dan sumbangan efektif sebesar $36,08 \%$, (2) terdapat kontribusi yang positif dan signifikan antara iklim kerja terhadap kinerja guru bimbingan konseling, sebesar $49,5 \%$, sumbangan relatif sebesar $86 \%$, dan sumbangan 
efektif $44,39 \%$, (3) terdapat kontribusi yang positif dan signifikan antara etos kerja terhadap kinerja guru bimbingan konseling sebesar $34,8 \%$, sumbangan relatif sebesar $23 \%$, dan sumbangan efektif sebesar $11,63 \%$ (4) secara bersama-sama terdapat kontribusi yang positif dan signifikan antara perilaku kepemimpinan kepala sekolah, iklim kerja dan etos kerja terhadap kinerja guru bimbingan konseling pada SMA se kabupaten Tabanan, dengan kontribusi sebesar $51,4 \%$, sumbangan relatif sebesar $179 \%$ dan sumbangan efektif sebesar $92,10 \%$. Dari paparan hasil diatas, maka dapat disimpulkan bahwa ketiga variabel tersebut dapat dijadikan prediktor kecendrungan kinerja perilaku kepemimpinnan kepala sekolah, iklim kerja dan etos kerja terhadap kinerja guru bimbingan konseling pada SMA se kabupaten Tabanan.

Kepemimpinan dalam penerapan manajemen sekolah memerlukan dua keterampilan yaitu keterampilan memimpin dan keterampilan mengelola (kepemimpinan dan manajerial). Perilaku kepemimpinan dalam melaksanakan keterampilan ini memegang peranan yang sangat penting untuk meningkatkan kualitas sekolah. Perilaku kepemimpinan yang positif dan mendukung terhadap penerapan manajemen kepala sekolah akan lebih mencapai keberhasilan. Guru memiliki peran strategis dalam bidang pendidikan, bahkan sumber daya pendidikan lain yang memadai sering kali kurang berarti apabila tidak disertai kualitas guru yang memadai dan peran yang strategis dari manajemen kepemimpinan kepala sekolah begitu juga sebaliknya. Di dalam usaha meningkatkan mutu pendidikan nasional harus dipertimbangkan juga mengenai kompetensi yang di miliki para guru. Kompetensi yang dimiliki oleh setiap guru akan menunjukkan kualitas guru dalam mengajar. Kompetensi tersebut akan terwujud dalam bentuk penguasaan pengetahuan dan profesional dalam menjalankan fungsinya sebagai guru. Kompetensi profesional guru adalah kompetensi atau kemampuan yang berhubungan dengan penyesuaian tugas-tugas keguruan. Kompetensi ini merupakan kompetensi yang sangat penting karena langsung berhubungan dengan kinerja yang ditampilkan. Dengan demikian manajemen kepemimpinan kepala sekolah mempunyai pengaruh terhadap keberhasilan kinerja guru dalam menjalankan tugas sebagai pengajar maupun pendidik.

Kinerja guru sangat penting untuk diperhatikan dan dievaluasi karena guru mengemban tugas profesional, artinya tugas-tugas tersebut hanya dapat dikerjakan dengan kompetensi khusus yang diperoleh melalui program pendidikan. Kompetensi yang dimiliki oleh seorang guru menjelaskan bahwa keprofesionalan dari seorang guru tidak hanya ditunjukkan pada saat guru berada dalam proses pembelajaran atau pada saat proses belajar mengajar berlangsung, namun keprofesionalan guru ditunjukkan lebih dari itu, dalam arti mampu dan senantiasa melaksanakan tugas-tugas keguruannya sesuai dengan bidangnya. Dengan kata lain, kompetensi profesional guru dapat mempengaruhi kinerja guru itu sendiri.

Berdasarkan pemaparan di atas, maka dapat disimpulkan bahwa kepemimpinan memberikan kontribusi yang signifikan terhadap kinerja guru di SMK Negeri 2 Singaraja.

\section{Kontribusi Etos Kerja terhadap Kinerja Guru di SMKN 2 Singaraja}

Berdasarkan analisis data yang telah dilakukan, secara normatif ditemukan bahwa etos kerja berada pada kategori sangat baik. Selain itu, hasil analisis juga menunjukkan bahwa terdapat korelasi yang signifikan antara etos kerja dengan SMK Negeri 2 Singaraja melalui persamaan garis regresi $\hat{y}=69,473+0,982 X 2$ dengan Freg $=39,162(p<0,05)$. Sedangkan korelasi yang signifikan terjadi antara etos kerja dengan kinerja guru sebesar 0,564 dengan $\mathrm{p}<0,05$ dan variabel etos kerja dapat menjelaskan SMK Negeri 2 Singaraja sebesar 31,8\%. Temuan ini mengindikasikan bahwa etos kerja mempunyai peranan penting dalam meningkatkan kinerja guru di SMK Negeri 2 Singaraja. Sumbangan efektif (SE) variabel kepemimpinan kepala sekolah terhadap kinerja guru di SMK Negeri 2 Singaraja adalah sebesar $13,61 \%$.

Temuan dalam penelitian ini sejalan dengan temuan penelitian yang dilakukan oleh Suardana (2015) dengan judul Kontribusi Persepsi Guru Tentang Gaya Kepemimpinan 
Kepala Sekolah, Motivasi Kerja dan Etos Kerja terhadap Kinerja Guru Bahasa Inggris SMA di Kabupaten Tabanan. Hasil analisis ditemukan: (1) terdapat kontribusi yang positif dan signifikan gaya kepemimpinan kepala sekolah terhadap kinerja guru melalui persamaan garis regresi $=3,632+0,961 \times 1$ dengan Freg $=23,644(p<0,05)$ dan sumbangan efektif sebesar 10,30\%, (2) terdapat kontribusi yang positif dan signifikan motivasi kerja terhadap kinerja guru melalui persamaan garis regresi: $=42,481+0,577 \mathrm{X} 2$ dengan Freg $=21,662$ $(p<0,05)$ dan sumbangan efektif sebesar $11,90 \%$, (3) terdapat kontribusi yang positif dan signifikan etos kerja terhadap kinerja guru melalui persamaan garis regresi $=18,715+0,816$ X3 dengan Freg $=66,552(p<0,05)$ dan sumbangan efektif sebesar 40,90\%, dan (4) terdapat kontribusi yang positif dan signifikan secara bersama-sama gaya kepemimpinan kepala sekolah, motivasi kerja, dan etos kerja terhadap kinerja guru melalui persamaan garis regresi $=13,854+0,317 X 1+0,234 X 2+0,594 X 3$ dengan Freg $=28,487(p<0,05)$ dengan kontribusi sebesar $63,10 \%$. Berdasarkan hasil temuan tersebut dapat disimpulkan bahwa terdapat kontribusi yang positif dan signifikan gaya kepemimpinan kepala sekolah, motivasi kerja, dan etos kerja terhadap kinerja guru Bahasa Inggris SMA di Kabupaten Tabanan secara terpisah maupun simultan. Dengan demikian ketiga faktor tersebut dapat dijadikan prediktor tingkat kecenderungan kinerja guru Bahasa Inggris SMA di Kabupaten Tabanan.

Etos kerja berarti semangat yang dimiliki seseorang, yang kelak akan bermanfaat untuk dirinya maupun dalam upaya mendukung dan bekerja sama dengan pihak lain. Tidak ada orang berhasil dengan bermodalkan kemalasan, bekerja asal-asalan dan tidak bertanggung jawab apalagi ini dilakukan oleh seorang guru. Guru harus memiliki etos kerja yang baik supaya anak yang didiknya juga menjadi anak yang benar-benar dapat menjadi anak berguna, memiliki prestasi, baik dalamn keluarga maupun di masyarakat. Hanya ada satu untuk berhasil yaitu gigih dalam kesulitan dan tanggungjawab dalam prestasi. Etos kerja adalah sesuatu yang harus di lakukan seseorang. Keharusan sesuai dengan peranannya sebagai seorang tenaga pendidik.

Makna kinerja mencakup: 1) kemampuan; 2) penerimaan tujuan-tujuan organisasi; 3) tingkatan tujuan-tujuan yang hendak dicapai; dan 4) interaksi antara tujuan dengan kemampuan para anggota organisasi tersebut. Dalam kamus besar bahasa Indonesia, kinerja diartikan sebagai 1) sesuatu yang dicapai; 2) prestasi yang diperlihatkan; dan 3) kemampuan kerja. Sementara Stolovitch (1992:256) mengemukakan kinerja adalah hasil yang telah dicapai berhubungan dengan pelaksanaan dan prestasi kerja. Pendapat lain juga dikemukakan Prawirosentono (1999:125) yang mengartikan kinerja sebagai terjemahan dari kata performance, sebagai: 1) Melakukan/menjalankan; 2) memenuhi atau menjalankan kewajiban, 3) melakukan dan menyempurnakan tanggung jawab; dan 4) melakukan sesuatu yang diharapkan seseorang.

Dari uraian diatas seorang guru yang memiliki semangat yang tinggi dan ingin melaksanakan tugas sesuai dengan kemampuannya disebut orang yang yang memiliki etos kerja yang tinggi, dengan demikian kinerja guru sangat dideterminasi oleh etos kerja yang tinggi untuk mencapai suatu tujuan.

Berdasarkan pemaparan di atas, maka dapat disimpulkan bahwa etos kerja memberikan kontribusi yang signifikan terhadap kinerja guru di SMK Negeri 2 Singaraja.

\section{Kontribusi Kepuasan Kerja terhadap Kinerja Guru di SMKN 2 Singaraja}

Berdasarkan analisis data yang telah dilakukan, secara normatif ditemukan bahwa kepuasan kerja berada pada kategori sangat baik. Selain itu, hasil analisis juga menunjukkan bahwa terdapat korelasi yang signifikan antara kepuasan kerja dengan kinerja guru di SMK Negeri 2 Singaraja melalui persamaan garis regresi $\hat{y}=70,830+0,966 \times 3$ dengan Freg $=$ $50,592(p<0,05)$. Sedangkan korelasi yang signifikan terjadi antara kepuasan kerja dengan kinerja guru sebesar 0,613 dengan $p<0,05$ dan variabel kepuasan kerja dapat menjelaskan kinerja guru di SMK Negeri 2 Singaraja sebesar 37,6\%. Temuan ini mengindikasikan bahwa kepuasan kerja mempunyai peranan penting dalam meningkatkan kinerja guru di SMK 
Negeri 2 Singaraja. Sumbangan efektif (SE) variabel kepuasan kerja terhadap kinerja guru di SMK Negeri 2 Singaraja adalah sebesar 16,75\%.

Hasil penelitian ini sejalan dengan hasil penelitian yang dilakukan oleh Sudanta (2013) yang berjudul Determinasi Sikap Guru Terhadap Profesinya, Kemampuan Mengelola Proses Pembelajaran dan Gaya Kepemimpinan Kepala Sekolah Terhadap Kepuasan Kerja Guru Sekolah Dasar. Hasil penelitian menunjukkan bahwa: 1) terdapat determinasi yang signifikan antara sikap guru terhadap profesinya terhadap kepuasan kerja guru SD dengan koefisien korelasi sebesar 0,473 dan sumbangan efektifnya sebesar $13,1 \%, 2$ ) terdapat determinasi yang signifikan antara kemampuan mengelola proses pembelajaran terhadap kepuasan kerja guru SD dengan koefisien korelasi sebesar 0,461 dan sumbangan efektifnya sebesar $13,8 \%, 3)$ terdapat determinasi yang signifikan antara gaya kepemimpinan kepala sekolah terhadap kepuasan kerja guru SD dengan koefisien korelasi sebesar 0,465 dan sumbangan efektifnya sebesar $12,7 \%$, 4) secara bersama sama, terdapat determinasi yang signifikan antara sikap guru terhadap profesinya, kemampuan mengelola proses pembelajaran, dan gaya kepemimpinan kepala sekolah terhadap kepuasan kerja guru SD dengan koefisien korelasi ganda sebesar 0,692 dan kontribusinya sebesar 39,6\% terhadap kepuasan kerja guru sekolah dasar di Gugus I Kecamatan Sukasada, Kabupaten Buleleng.

Pertama, kepuasan kerja merupakan bentuk respon pekerja terhadap kondisi lingkungan pekerjaan. Kedua, kepuasan kerja sering ditentukan oleh hasil pekerjaan atau kinerja. Ketiga, kepuasan kerja terkait dengan sikap lainnya dan dimiliki oleh setiap pekerja. Pencapaian suatu tujuan tidak terlepas dari kepuasan kerja dalam bekerja, karena kepuasan kerja juga dapat menciptakan semangat dan kemauan untuk bekerja dalam mencapai keberhasilan kerja guru. Dengan adanya kepuasan kerja akan berdampak pada kinerja guru. Dengan kata lain, seorang guru akan melakukan semua pekerjaannya dengan baik apabila terciptanya kepuasan kerja dalam suatu pekerjaan dalam suatu lingkungan tertentu.

Berdasarkan pemaparan di atas, maka dapat disimpulkan bahwa kepuasan kerja memberikan kontribusi yang signifikan terhadap kinerja guru di SMK Negeri 2 Singaraja.

\section{Kontribusi Budaya Organisasi terhadap Kinerja Guru di SMKN 2 Singaraja}

Berdasarkan analisis data yang telah dilakukan, secara normatif ditemukan bahwa budaya organisasi berada pada kategori sangat baik. Selain itu, hasil analisis juga menunjukkan bahwa terdapat korelasi yang signifikan antara budaya organisasi dengan kinerja guru di SMK Negeri 2 Singaraja melalui persamaan garis regresi $\hat{y}=64,059+$ $1,014 X 4$ dengan Freg $=39,106(p<0,05)$. Sedangkan korelasi yang signifikan terjadi antara budaya organisasi dengan kinerja guru sebesar 0,564 dengan $p<0,05$ dan variabel kepuasan kerja dapat menjelaskan kinerja guru di SMK Negeri 2 Singaraja sebesar 31,8\%. Temuan ini mengindikasikan bahwa budaya organisasi mempunyai peranan penting dalam meningkatkan kinerja guru di SMK Negeri 2 Singaraja. Sumbangan efektif (SE) variabel budaya organisasi terhadap kinerja guru di SMK Negeri 2 Singaraja adalah sebesar 13,73\%.

Hasil penelitian ini sejalan dengan hasil penelitian yang dilakukan oleh Pancaria (2015) dengan judul Kontribusi Efektivitas Kepemimpinan, Budaya Organisasi dan Etos Kerja Terhadap Kepuasan Kerja Pegawai Kantor Kementerian Agama Kabupaten Buleleng. Berdasarkan penelitian yang telah dilakukan, didapatkan hasil bahwa: 1) terdapat kontribusi yang signifikan dari efektivitas kepemimpinan terhadap kepuasan kerja pegawai kantor Kementerian Agama Kabupaten Buleleng, 2) terdapat konstribusi yang signifikan dari budaya organisasi terhadap kepuasan kerja pegawai kantor Kementerian Agama Kabupaten Buleleng, 3) terdapat kontribusi yang signifikan dari etos kerja terhadap kepuasan kerja pegawai kantor Kementerian Agama Kabupaten Buleleng, dan 4) terdapat kontribusi yang signifikan secara bersama-sama antara efektivitas kepemimpinan, budaya organisasi dan etos kerja terhadap kepuasan kerja pegawai kantor Kementerian Agama Kabupaten Buleleng. Dengan demikian, efektivitas kepemimpinan, budaya organisasi dan etos kerja dapat dijadikan sebagai prediktor dalam peningkatan kepuasan kerja pegawai kantor Kementerian Agama Kabupaten Buleleng. 
Budaya organisasi merupakan nilai-nilai dan norma yang dianut dan dijalankan oleh sebuah organisasi terkait dengan lingkungan di mana organisasi tersebut menjalankan kegiatannya. Budaya organisasi merupakan "apa yang dirasakan, apa yang diyakini, dan apa yang dijalani” oleh sebuah organisasi. Budaya Organisasi dapat didefinisikan sebagai yang telah dipelajari oleh para anggota organisasi sewaktu memecahkan masalah-masalah yang dihadapi dalam upaya melakukan adaptasi eksternal dan integrasi internal yang berhasil cukup baik sehingga dianggap cukup sah. Oleh karena itu akan diajarkan kepada para anggota baru sebagai cara yang benar untuk mempersepsi, berpikir dan merasa dalam hubungan dengan masalah-masalah yang dihadapi organisasi.

Budaya organisasi dan kepemimpinan merupakan dua sisi mata uang logam yang sama, yaitu para pemimpin yang pertama menciptakan budaya pada saat mereka mendirikan kelompok dan organisasi. Begitu budaya terbentuk, budaya itu menetapkan kriteria untuk kepemimpinan, sehingga dengan demikian menentukan siapa yang menjadi atau tidak menjadi pemimpin budaya organisasi yang kondusif menciptakan, meningkatkan dan mempertahankan kinerja tinggi.

\section{Kontribusi Kepemimpinan Kepala Sekolah, Etos Kerja, Kepuasan Kerja, dan Budaya Organisasi Sekolah terhadap Kinerja Guru di SMKN 2 Singaraja}

Berdasarkan analisis yang telah dilakukan, ditemukan bahwa terdapat korelasi yang signifikan secara bersama-sama antara kepemimpinan kepala sekolah, etos kerja, kepuasan kerja, dan budaya organisasi terhadap kinerja guru melalui persamaan garis regresi $\hat{y}=33,447+0,305 X 1+0,420 X 2+0,430 X 3+0,438 X 4$ dengan Freg $=24,516$ $(p<0,05)$. Ini berarti terdapat hubungan secara bersama-sama antara kepemimpinan, etos kerja, kepuasan kerja, dan budaya organisasi terhadap kinerja guru di SMK Negeri 2 Singaraja. Hal ini mengindikasikan bahwa makin baik kepemimpinan, etos kerja, kepuasan kerja, dan budaya organisasi makin baik pula kinerja guru tersebut.

Korelasi murni antara kepemimpinan, etos kerja, kepuasan kerja, dan budaya organisasi dengan kinerja guru di SMK Negeri 2 Singaraja yang diperoleh melalui analisis korelasi parsial jenjang kedua. Hasil yang diperoleh adalah: pertama, terdapat korelasi yang signifikan antara variabel kepemimpinan terhadap kinerja guru dengan dikendalikan oleh variabel etos kerja, kepuasan kerja, dan budaya organisasi $\left(r_{1 y-234}=0,517\right)$ dengan $p<$ 0,05). Ini menunjukkan bahwa kepemimpinan memberikan kontribusi yang signifikan terhadap kinerja guru di SMK Negeri 2 Singaraja, sehingga dapat dijadikan prediktor kecenderungan tingkat kinerja guru di SMK Negeri 2 Singaraja.

Kedua, terdapat korelasi yang signifikan etos kerja terhadap kinerja guru dengan dikendalikan oleh variabel kepemimpinan, kepuasan kerja, dan budaya organisasi $\left(r_{2 y-134}=\right.$ $0,564$ dengan $p>0,05)$. Ini menunjukkan bahwa etos kerja memberikan kontribusi terhadap kinerja guru di SMK Negeri 2 Singaraja, sehingga dapat dijadikan prediktor kecenderungan tingkat kinerja guru di SMK Negeri 2 Singaraja.

Ketiga, terdapat korelasi yang signifikan antara kepuasan kerja terhadap kinerja guru dengan dikendalikan oleh variabel kepemimpinan, etos kerja, dan budaya organisasi $\left(r_{3 y-124}\right.$ $=0,613$ dengan $p>0,05$ ). Ini menunjukkan bahwa kepuasan kerja memberikan kontribusi terhadap kinerja guru di SMK Negeri 2 Singaraja, sehingga dapat dijadikan prediktor kecenderungan tingkat kinerja guru di SMK Negeri 2 Singaraja.

Keempat, terdapat korelasi yang signifikan antara budaya organisasi terhadap kinerja guru dengan dikendalikan oleh variabel kepemimpinan, etos kerja dan kepuasan kerja $\left(r_{4 y}\right.$ $123=0,564$ dengan $p>0,05)$. Ini menunjukkan bahwa budaya organisasi memberikan kontribusi terhadap kinerja guru di SMK Negeri 2 Singaraja, sehingga dapat dijadikan prediktor kecenderungan tingkat kinerja guru di SMK Negeri 2 Singaraja.

Kekuatan hubungan keempat variabel bebas dengan kinerja guru di SMK Negeri 2 Singaraja secara berurutan adalah: kepemimpinan, etos kerja, kepuasan kerja, dan budaya organisasi mempunyai kontribusi terhadap kinerja guru. 


\section{PENUTUP}

Berdasarkan hasil penelitian dan pembahasan yang telah dilakukan, maka dapat ditarik kesimpulan sebagai berikut.

Pertama, ada kontribusi yang signifikan antara kepemimpinan terhadap kinerja guru di SMK Negeri 2 Singaraja dengan koefisien korelasi sebesar 0,517 dan sumbangan efektifnya sebesar $10,74 \%$.

Kedua, ada kontribusi yang signifikan antara etos kerja terhadap kinerja guru di SMK Negeri 2 Singaraja. dengan koefisien korelasi sebesar 0,564 dan sumbangan efektifnya sebesar $13,61 \%$.

Ketiga, ada kontribusi yang signifikan antara kepuasan kerja terhadap kinerja guru di SMK Negeri 2 Singaraja dengan koefisien korelasi sebesar 0,613 dan sumbangan efektifnya sebesar $16,75 \%$.

Keempat, ada kontribusi yang signifikan antara budaya organisasi terhadap kinerja guru di SMK Negeri 2 Singaraja dengan koefisien korelasi sebesar 0,564 dan sumbangan efektifnya sebesar $13,73 \%$.

Kelima, secara bersama-sama, ada kontribusi yang signifikan antara kepemimpinan, etos kerja, kepuasan kerja, dan budaya organisasi terhadap kinerja guru di SMK Negeri 2 Singaraja dengan koefisien korelasi ganda sebesar 0,794 dan kontribusinya sebesar $54,8 \%$ terhadap kinerja guru di SMK Negeri 2 Singaraja.

Berdasarkan hasil dan kesimpulan dari penelitian ini, dapat diajukan beberapa saran sebagai berikut.

Guru hendaknya mampu untuk meningkatkan budaya organisasi sehingga kinerja guru dapat ditingkatkan. Hal ini bertujuan agar proses pembelajaran yang ada di sekolah dapat berjalan secara optimal, sehingga tujuan pembelajaran yang ingin dicapai dapat tercapai secara maksimal.

Kepala sekolah hendaknya mampu untuk meningkatkan kepemimpinannya, sehingga kepala sekolah akan menjadi panutan bagi guru dan staf yang ada di sekolah. Selain itu kepala sekolah hendaknya juga mampu untuk mengayomi seluruh bawahannya sehingga kegiatan-kegiatan di sekolah dapat berjalan dengan optimal.

Peneliti lain diharapkan mampu mengembangkan variabel lain dalam usaha meningkatkan kinerja guru, sehingga dapat memberikan kontribusi pengetahuan.

\section{DAFTAR RUJUKAN}

Agung, Anak Agung Gede. 2014. Metodologi Penelitian Pendidikan. Malang: Aditya Media Publishing.

Agung, Anak Agung Gede. 2016. Statistika Dasar untuk Pendidikan. Yogyakarta; Depublish.

Arikunto, S. 2006. Prosedur Penelitian Suatu Pendekatan Praktik, Ed Revisi VI. Jakarta: Penerbit PT Rineka Cipta.

Arikunto, Suharsimi. 1995. Manajemen Penelitian. Jakarta: Rineka Cipta.

Arikunto, Suharsimi. 1997. Prosedur Penelitian Suatu Pendekatan Praktek. Jakarta: Rineka Cipta.

Asricita, Ni Made. 2015. Kontribusi Perilaku Kepemimpinan Kepala Sekolah, Iklim Kerja, dan Etos Kerja Terhadap Kinerja Guru Bimbingan Konseling Pada SMA Se Kabupaten Tabanan. e-Journal Program Pascasarjana Universitas Pendidikan Ganesha. Program Studi Administrasi Pendidikan Volume 6, No 1.

Depdiknas. 2008. Kurikulum Tingkat Satuan Pendidikan. Jakarta: Dikmenum. 
Djamarah, Syaiful Bahri. 2000. Guru dan Anak Didik dalam Interaksi Edukatif. Jakarta: Rineka Cipta.

Hamzah, B. Uno. 2007. Teori Motivasi dan Pengukurannya. Jakarta: Bumi Aksana.

Luthans, Fred. 1995. Organizational Behavior. Mc.Graw Hill International, New York.

Mulyasa, E. 2004. Implementasi Kurikulum Berbasis Kompetensi. Bandung: Cipta Cekas Grafika.

Pancaria, I Nyoman. 2015. Kontribusi Efektivitas Kepemimpinan, Budaya Organisasi dan Etos Kerja Terhadap Kepuasan Kerja Pegawai Kantor Kementerian Agama Kabupaten Buleleng. e-Journal Program Pascasarjana Universitas Pendidikan Ganesha.Program Studi Administrasi Pendidikan Volume 6, No 1.

Puger, I Gusti Ngurah. 2004. Belajar Kooperatif. Diktat Perkuliahan Mahasiswa Unipas.

Robbins, Stephen P. 1996. Perilaku Organisasi, Konsep, Kontroversi dan Aplikasi. Alih Bahasa : Hadyana Pujaatmaka. Edisi Keenam. Jakarta: PT.Bhuana Ilmu Populer.

Smith, J.M., Van Ness, H.C., and Abbott, M.M., 1996. Introduction to Chemical Engineering Thermodynamics, 5 ed., New York: Mc.Graw Hill Book Company, Inc.

Suardana, Putu. 2015. Kontribusi Persepsi Guru Tentang Gaya Kepemimpinan Kepala Sekolah, Motivasi Kerja dan Etos Kerja terhadap Kinerja Guru Bahasa Inggris SMA di Kabupaten Tabanan. e-Journal Program Pascasarjana Universitas Pendidikan Ganesha. Program Studi Administrasi Pendidikan Volume 6, No 1.

Sudanta, I Wayan. 2013. Determinasi Sikap Guru Terhadap Profesinya, Kemampuan Mengelola Proses Pembelajaran dan Gaya Kepemimpinan Kepala Sekolah Terhadap Kepuasan Kerja Guru Sekolah Dasar. e-Journal Program Pascasarjana Universitas Pendidikan Ganesha. Program Studi Pendidikan Dasar Volume 3, No 1.

Sugiyono. 2010. Metode Penelitian Administrasi: Pendekatan Kuantitatif, Kualitatif, dan R\&D. Bandung: Alfabeta.

Sunyoto, Agus. 2008. Manajemen Sumber Daya Manusia. Jakarta: Badan Penerbit IPWI.

Suryanti, Sri. 1995. Psikologi Perusahaan. Jakarta: Rineka Cipta. 